RESIDENT

\& FELLOW

SECTION

Section Editor

Mitchell S.V. Elkind,

MD, MS

\title{
Right Brain: \\ The disentanglement
}

She was sobbing. Her husband, eyes lowered, turned his head slowly in disapproving judgment. With his tan-colored hat affixed tightly to his tancolored head, he slouched further in his seat. David, also slouched on the patient table, seemed completely uninterested in the parental affair. He had his own tension. Head bowed, he desperately clutched his flexed right hand with his left. This was my first visit. These were the Almadys.

"How are you feeling?" I asked, hoping to break the tension. David only shrugged his shoulders. "All right, I guess," he replied, his impossibly oversized t-shirt draped over his bony, 14year-old shoulders. Six months ago, David had suffered a left basal ganglia stroke related to an internal carotid artery dissection. Three months later he arrived at the emergency department complaining of severe arm pain. Imaging suggested a possible second stroke. One month ago he developed a significant dystonia in his right arm. And on the day of the sobbing, I began a longitudinal program at my medical school which paired medical students with physician mentors and their patients.

David's examination was revealing. As he walked down the hallway his right arm twisted behind him. His left hand, a compassionate figure, reached out to grab his right wrist. "David, put your left hand by your side," the physician said gently. With that instruction, we watched as his right hand lifted away from his body, now freely subject to the whims of his dysfunctional left basal nuclei. For David, it was not a pleasant liberation. With his left arm hanging loosely by his side, the contralateral nature of the brain had never been so apparent.

The medications were clearly not working. David had lost 30 pounds since the stroke, Mom was emotionally unstable, and Dad was not engaged. The previous week, the family had seen a psychiatrist-someone on the father's health plan-who discontinued the Klonopin without consulting any of David's physicians. "Oh, and we can't really do physical therapy because his father's insurance doesn't cover that." Never had the complexity of illness been so apparent.

Before David's stroke, he and his father were, as his mother once said, "almost like the same person. You couldn't separate them.” In particular, Mr. Almady's memory of his son before the stroke was inextricably bound up with athletics. "He was an athlete. Basketball, football, whatever," he would tell me at one of David's visits, the glimmer in his eyes betraying the joy that must have been. For him, David's dystonia and subsequent movement limitations represented a uniquely existential challenge-an event which demanded a fundamental reconceptualization of who David was.

Illness has a peculiar way of pressing-sometimes gently and oftentimes forcefully- on the fibrous fabric of our lives. And with time, the illness - or rather the meaning that the illness comes to represent-becomes deeply enmeshed into the fabric itself. During that process there are often tears in the fibers that were, perhaps, already frayed.

There were signs. At first, they failed to return my phone calls_-six of them. Then, their home phone number changed. I would later learn that Mr. Almady was having an extramarital affair. His female companion was calling the home in what, according to Mrs. Almady, "was nothing but disrespectful to me. And then David found out about it." Since the affair, I have watched David's relationship with his father progressively deteriorate. And as the dystonia worsens, it is almost as if David is carrying the mounting tension of his life in his painfully clenched right hand.

For David, the fabric of his life remains largely unknown. Often unable to inspire clarity or reflection from David, I often find myself discussing 
home run totals and basketball scoring averages. But perhaps David's insistence on conversing about sports is not trivial. Perhaps this is the answer to his own existential question-resolving the tension between what he once was ("the athlete") and the reality of what he now is.

And still, David remains an enigma. When asked what he thought when he was told he had a stroke, he shrugged indifferently: "I don't know. It wasn't a big deal to me. It was like I had a cold or something." But perhaps these words are not entirely reflective of his truth. Recent neuropsychological testing involved extensive questionoriented exercises. On one particular part of the examination, David's responses included "I am almost always blamed for things I can't help" and "even when I try hard, I fail." His fibers, perhaps, are fraying silently from within.

Foucault ends his seminal text "The Birth of the Clinic" by noting that "we are only just begin- ning to disentangle a few of the threads ... [that] have constituted the dark, but firm web of our experience." ${ }^{1}$ David's stroke has shorn fibers of an old self-image, supported and shared by his father. I have watched as both of them struggle to mend the tear. And though the neurologic outcome remains uncertain, I know that I must continue to support this family as they seek to incorporate the meanings of David's stroke into their lives. Indeed, inquiry into how an illness comes to be enmeshed in the fabric of a patient's life - and how the meanings of illness mediate that process-ought to underlie the basis of our interaction with patients and their families. This endeavor, then, represents only the beginning of the disentanglement.

\section{REFERENCE}

1. Foucault M. The Birth of the Clinic. Translated from the French by A.M. Sheridan Smith. New York: Pantheon Books; 1973. 


\section{Neurology}

Right Brain: The disentanglement

Neal A. Chatterjee

Neurology 2008;70; e55-e56

DOI 10.1212/01.wnl.0000309215.88999.9f

This information is current as of May 20, 2008

\section{Updated Information \&} Services

Subspecialty Collections

Permissions \& Licensing

Reprints including high resolution figures, can be found at: http://n.neurology.org/content/70/16/e55.full

This article, along with others on similar topics, appears in the following collection(s):

Basal ganglia

http://n.neurology.org/cgi/collection/basal_ganglia

\section{Childhood stroke}

http://n.neurology.org/cgi/collection/childhood_stroke

\section{Dystonia}

http://n.neurology.org/cgi/collection/dystonia

Information about reproducing this article in parts (figures,tables) or in its entirety can be found online at:

http://www.neurology.org/about/about_the_journal\#permissions

Information about ordering reprints can be found online:

http://n.neurology.org/subscribers/advertise

Neurology ${ }^{\circledR}$ is the official journal of the American Academy of Neurology. Published continuously since 1951, it is now a weekly with 48 issues per year. Copyright. All rights reserved. Print ISSN: 0028-3878. Online ISSN: 1526-632X.

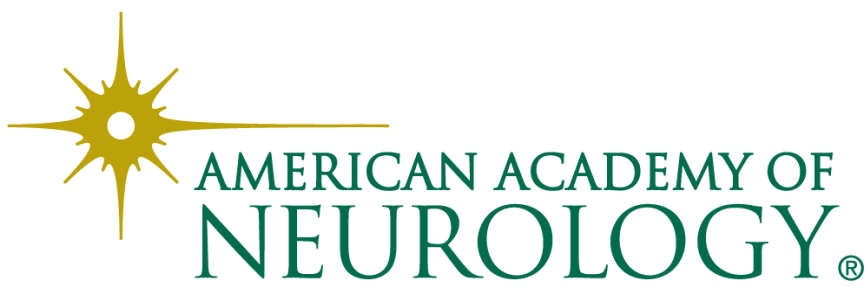

